\title{
Minorities in Graeco Roman Alexandria: A Religious or a Racial Issue?
}

\author{
Shaza Ismail \\ Faculty of Tourism and Hotels, Helwan University
}

\begin{abstract}
"The First City of the Civilized World" is the ideal description for the city of Alexandria, Egypt, in the fourth century BC. Despite the existence of many other cities carrying the name of Alexander the Great, the Alexandria he built in Egypt remained the most distinctive over three centuries. Built by the architect Dinocrates after being commissioned by Alexander the Great in April 331 B.C.E to design and construct a city carrying his name to be a hub where existing and ancient civilizations would interact. The city was built on a grid as a metropolis during the era of Antiquity (or Hellenistic Era). Like any populated city, Alexandria was a well situated city for many opportunities and attracted immigrants from all parts of the Greek empire. Though Alexandria was inhabited by a Greek majority, the city was home to many minority and immigrant populations - the largest of these being the Jewish and native Egyptian communities. Divisions of these inhabitants were not only based on race, but also were based on religion. This article discusses the different groups of minorities in Graeco Roman Alexandria, their role in the society, their relations with their each other and whether the distinction of these groups was based on race or religion.
\end{abstract}

Keywords: Ethnic, minorities, negroids, Jews, Frumentius, the Alexandrian community, Cyrus of Persia, El Shaddai, Septuagint, Ethiopians.

\section{Background:}

Alexandria was a center for the Classical World in terms of commerce and culture. It had all what is considered today to be the characteristics of a civilized city, i.g. the Roman theatre, the council halls, the law courts, the gymnasium and the temples of Greek gods in addition to many other elements of the Graeco-Roman culture (Watts, 2008). Looking at the ethnic structure of the population we find that the three largest groups of people within the city were the Greeks, the Jews, and the Egyptians, who all went through a series of conflicts with each other (Forster, 1961). The Egyptian section was known as Rhakotis which include Pompey's Pillar, the famous Serapium, and the catacombs. The Greek section was known as Bruchium, which was the most popular part of the city, containing Europeans and Asians. The Jewish region, known as Delta, was walled and in a way it was a separate city completely culture-wise (Vrettos, 2001).

\section{Introduction}

Various references describing the size and ethnic structure of the population of Alexandria in the early centuries do exist. Philo Judaeus (20 BC - 50 AD), a Hellenistic Jewish philosopher from Alexandria, mentioned that one million Jews lived in Egypt. Many scholars suggested that the ratio of the Jews was 1:7 to the total inhabitants of Egypt. Josephus (37 AD - 100 AD), a Roman Jewish, renowned scholar, indicated that 50,000 of all Jews had been massacred in the Delta district in $61 \mathrm{AD}$. Assuming that Josephus indications are correct and taking the above mentioned ratio in consideration the size of the Alexandrian population could be estimated to be well over 350,000 residents. By the time of the Arabs (641 AD-642 AD), Abdel Hakam (803 A.D - 871 A.D), a Muslim historian, documented in "The Conquest of Egypt and North Africa and Spain" known as "The Futuh Misr" that Amr Ibn El Aas the leader of the Muslim army reported to Omar the, Muslim Caliph, that he found 40,000 Jews in Alexandria paying taxes. With the increase of the population of Egypt and Alexandria during the time of the Romans, the number of residents of Alexandria reached 500,000 to 600,000 with an estimated number of 180,000 Jews forming 30 to 36 percent. This increase in the number of Jews living in the city could be due to the conquests of Coelle (274 BC - 168 BC), Syria, resulting in an influx of Judean residents. The status in this dichotomy of citizen and non-citizen had been hazy and inconsistent. This ambiguity increased greatly after the Roman takeover, and greatly increased tensions with both Greek and Egyptian residents of the city (Bell, 1941).

These differentials were reinforced by different rates of taxation, and placed the Greeks highest and most 'urban', and the native Egyptian population at the bottom, being 'rural' and based largely in the countryside rather than in the Alexandrian city-center itself (Alston, 1997).

\section{Ethnic Minorities of Alexandria}

Jews were not the only minority in Alexandria. Although the Jewish population of Alexandria was the most influential due to their size, there existed alongside other minorities e.g. Nubians/Negroids and Pagans. Evidence of the existence of other minorities could be traced through the different products which existed in Alexandria from India, China, Greece, Africa, Sparta, and Elea in Italy, Carthage, Marseilles, Persia and Rome. The Septuagint version of the Old Testament is another evidence of the different groups. It was translated to their languages as to be easily understood, examples of these languages were Coptic, Syriac and Armenian. Those minorities played an influential role in the 
history of the city and had their impact on trade, history, tradition and culture resulting in creating a multicultural society. By the middle of the third century BC Alexandria attracted many racial groups basically for trade.

Despite the lack of strong evidence of the contribution of those ethnic groups to the Alexandrian society due to their prosecution for not being Greek, the legacy that was left by such minorities cannot be ignored. For example: Negroids or people of Kush and Axum origins, scholars and anthropologists categorize them as Ethiopians, have occupied Egypt from the early second century to the end of antiquity. Many cultural achievements were attributed to them e.g. the creation of alphabet, decorated pottery, the international trading system that extended from Southeast Asia to the Mediterranean and iron that resides in the hinterlands of the Upper Nile Valley. Such minorities were hated because of their exclusive communities, thus causing various revolts and wars in Alexandria, Egypt (Burstein, 1998)

\section{The Alexandrian community:}

\section{The Jews:}

Once hearing of Alexandria's completed construction, many of the people in Jerusalem decided to migrate there, bringing their Jewish religion with them (Forster 1961). The Jews made their journey to Alexandria in the $3^{\text {rd }}$ century B.C.E (Riggs, 2012). Already being very accepting of the Egyptian religious customs, Alexander the Great was open to let the Jews maintain their ways of worship. The Jews made up the fourth district of Alexandria, which was known as the Delta district (Forster 1961)

The Jews very much adapted to the Greek language and began speaking it, while abandoning many of their previous customs. This led to the creation of the Septuagint, the Old Testament, which was completely translated into Greek language in 130 B.C. There is a legend that states in order to obtain the best translation, the Ptolemaic ruler Ptolemy Philadelphis ordered seventy rabbis into isolation to translate the Old Testament from Hebrew to Greek (Forster, 1961). Within their section of Alexandria, the Jews were then divided based on social class and there is barely information regarding the lower class Jews in Alexandria (Pearson, 2003). While under Roman occupation, the Jewish community made up approximately $36 \%$ of Alexandria and actually participated in paying taxes (Delia, 1988).

It should be no surprise then that a new city that hoped to become one of the greatest in the world - if not the greatest - would attract Jewish immigrants - indeed, it was very nearly right at their doorstep. As people with a history of traveling through the region, Alexandria's first Jewish inhabitants were probably comfortable with moving to the city. They came from the groups that fled to Egypt in $586 \mathrm{BCE}$ and from the former kingdom of Judah to the city named after the man who had conquered the mighty Persian Empire, and mostly settled in the Delta quarter of the city, near the sea shore. One of the early Ptolemies had assigned them to that quarter, though they were not restricted to this region of the city - indeed, they began to overflow the Delta quarter and spill over into other sections of the city, nearly making up another quarter of the city. Among their greatest concerns were their ability to practice their religion and their legal status in the city of Alexandria, namely their lack of citizenship. The Ptolemaic dynasty allowed the Jewish community a great deal of self-government and was generally tolerant of their religious differences. H. I. Bell writes, "There seems to have been a superior and an inferior class within the community, which was governed at first by elders and later by an official known variously as genarch or ethnarch. In Roman times we hear of a gerusia or council of elders, probably containing 71 members." Despite their wide-ranging ability to govern themselves, perhaps even better than the other inhabitants of the city, the Jews of Alexandria seem to have been denied citizenship. They did enjoy some rights that were only available to citizens, and some individuals might have achieved citizenship, but for the most part Jews were not official citizens of Alexandria (Bell, 1941)

Although they lacked formal citizenship, the Jews of Alexandria were still important in the life of the city. They took on all kinds of work - they never grew exceptionally wealthy as a whole, and were present in most professions that could be found in the city. The tales of Alexander the Alabarch, the extremely rich brother of the famous writer Philo, were mistaken to be representation of the Jewish community's prosperity, when it was in fact only the prosperity of a powerful family who just happened to be Jews. Not only were Jews present and engaged in the economic life of the city, but they contributed to the cultural legacy of Alexandria. This legacy continued past the Ptolemaic period - authors such as Philo, who was a Hellenistic Jewish philosopher who lived from 20 BCE to 50 CE, wrote philosophical works that were either related to or influential on early Christian thought. Philo wrote that Yahweh had formed a master plan, called a logos, of creation - an idea that borrowed heavily from Plato's philosophy, an indicator of how Hellenized the Jews of Alexandria had become. The Septuagint was another such indicator; a Greek version of the Torah, it not only served the needs of a Jewish community that had largely abandoned Hebrew, it also was the first translation of its kind, opening the religious ideology and history of the Jews to the Greek-speaking world for the first time. It later became the basis for the Old Testament of the Christian Orthodox Church (Armstrong, 1993)

Yet, despite a great amount of cultural assimilation, the Jews were still not officially regarded as citizens. The Ptolemaic kingdom had been rather careful about the subject, granting the Jews some privileges but stopping short of citizenship. When the Romans conquered Egypt in the late first century BCE, they were vaguer still, though the political situation of the city had changed greatly since its incorporation into the Empire. Perhaps the most noticeable for the Jewish inhabitants was that Greeks were no longer the ruling class of the city. And by Philo's time, some believe that forty percent of Alexandrians were Jews. Though there is no direct census or archaeological evidence for such a 
figure since most of Alexandria remains unexcavated, the figure is an estimate based on loosely related evidence. Whether or not this figure was accurate, the Romans hoped to make use of the Jewish community to balance out the demands of the Greeks and Egyptians in the city, and to this end their privileges were retained from the Ptolemaic period when the Romans took over. The Romans also expanded their religious freedoms - whereas the Greeks had been hostile to Jewish religion, sometimes referring to it as atheistic due to its denial of so many gods, the Romans had no such qualms. Religious toleration was a must in such a vast empire, and the Jews benefited from this slight relaxation of religious policy. The Roman period also witnessed various Jewish uprisings - no more than there had been under the Ptolemaic dynasty, but they were violent nonetheless. (Delia, 1998)

The Jews of Alexandria had a long history of moving throughout the Middle East and Egypt. When they settled in the city, they kept their identity and their religion, but acquired the language and much of the culture of the majority of its inhabitants. They were wealthy merchants, well-versed philosophers, generals, and everyday people who made up a surprisingly large portion of Alexandria's population, an immigrant minority in a city of immigrants. Although they were never accepted as citizens during the Greek or Roman periods - though they tried persistently throughout - they were still an important part of the city's life. They contributed to Alexandria's legacy as a great city, just as Alexandria itself contributed to the legacy of the Jews, and in turn the Christian and Muslim religions. Their contributions to theological thought, legal and religious principles, and their very act of settling in the city brought the history of Alexandria into the even longer history of the Jews (Bell, 1941)

The Jews that moved to Alexandria had a long and varied history by the time they arrived. Jewish tradition traces their lineage back to Abraham, who was originally from the city of Ur. Abraham was contacted by a god calling itself "El Shaddai," or El of the Mountain; El Shaddai promised Abraham that if he moved to Canaan and agreed to serve the god, his children would form a mighty nation and be more numerous than the stars. Abraham moved to the land of Canaan and possibly served the King of Sodom as a mercenary for a time, and then purchased land in Hebron in about 1850 BCE. Abraham's family or tribe, which he may have been chieftain or head of, followed him and settled with him on this land; they became known as the Hebrews. Abraham's grandson Jacob, renamed Israel later, led the Hebrews to settle in Shechem, modern Nablus. During a terrible famine, Jacob's sons led their people to Egypt, leaving some Hebrews in Egypt and some in Canaan. Around 1200 BCE, several Hebrew tribes arrived in Canaan from Egypt; their history reports that they were enslaved by the Egyptians and liberated by a god named Yahweh, the god of their leader, Moses. Yahweh had revealed itself to be the same god as the El Shaddai of Abraham, and Moses made a covenant with it at the top of Mount Sinai. It is around this time that the Hebrews became henotheistic, having been polytheistic before but placing special emphasis on El Shaddai; indeed, some of the commandments of the covenant Moses made with Yahweh were only sensible in a polytheistic setting, such as the commandment "Thou shall have no other gods before me," The Hebrews were now an ethnically, culturally, and historically diverse people with a number of different religious philosophies (Armstrong, 1993)

This diverse group of people created two kingdoms - Israel in the north, and Judah in the south. In 722 BCE, the kingdom of Assyria invaded and conquered the kingdom of Israel, and deported the population and forced them to assimilate into Assyrian culture. The kingdom of Judah was destroyed in 586 BCE by the Babylonians, and large numbers of Hebrews were deported to the Fertile Crescent, closer to Babylon; in 539 BCE, Cyrus of Persia conquered Babylon and later allowed the Hebrews taken from the former kingdom of Judah to return to their homeland. Many remained behind, but over 40,000 returned. The conflicts with Babylon and Assyria and the collapse of the Hebrew states had seen the culmination of a long process of reforming Hebrew religion - their religion was now almost exclusively monotheistic and was then known as Judaism, and the people of Judah known as Jews. Following the conquest of Judah by Babylon, some Jews also fled to Egypt, and they retained their identity and religion. The conquests of Alexander the Great in $332 \mathrm{BCE}$ and beyond created Hellenic states over the entirety of the world known to the Jewish people up to that point, and came into close contact with Greek philosophy and polytheism, which, by this point, was anathema to the Jews (Armstrong, 1993)

\section{The Jews and the Egyptians}

For the long history of both the Egyptian and Jewish communities in the middle South-Eastern Mediterranean, there were many instances of dispute between the two. In fact the most important foundation story regarding the spirit of the Jewish people, the story of Passover and the gift of Israel, revolves around the escape of the Hebrews from slavery in Israel. The Book of Exodus is full of tales involving the relations between the cultures, such the marriage of Ishmael to an Egyptian woman, and the harsh rule of Egypt over Canaan from 1500 to 1200 BCE. Jeremiah also wrote about the similarities between the Egyptians and Hebrews in their shared practice of circumcision. In these many traditions both biblical and historical there are demonstrated many interactions between the Jews and Egyptians with a foundation much deeper than their shared space in Alexandria (Biale, 2002).

\section{The Negroids:}

Negroids and the Graeco-Roman Empire came into contact when the Ptolemies wanted to poach elephants for ivory. But the Ptolemies and Ethiopians were in war in order to protect their interests in ivory in addition to gold found in the region. Because the Negroids lost the war, they were taken as a diplomatic agreement by Ptolemy II Philadelphus to Alexandria. The Negroids celebrated the festival of the god Dionysus, "the god that comes," by parading in the streets 
of Alexandria against their will and distributing ivory, ebony, gold and silver. Even though the Negroid warriors were taken as a diplomatic agreement, most Negroids were taken to Alexandria against their will as slaves. They were servants for pharaohs, nobility, priests and royal families, where 113,000 slaves would inhabit a temple. Male Negroid servants were cheaper than female Negroid slaves because the females became concubines for the Pharaoh. In addition, Negroids slaves were tattooed to mark their status as servants (Riggs, 2012)

Not only did the Greeks and Romans have Negroids as slaves, but some of wealthy from the Jewish community also had Negroid slaves. The Jewish community in Alexandria was there since the second century B.C. and refused to compromise their religious identity with the Greeks or Romans. However, the Jewish community was able to be employed in the bureaucracy as officials in Alexandria under the Greeks and Romans. Septuagint, or Jewish scholars, translates Jewish texts into Greek for their employers. In addition, the Jewish community became rich because of their increased prosperity as landowners and merchants of popular goods. Even within the Synagogue in Egypt, there were various places for craft associations specialized in popular goods, blacksmiths, silversmiths, goldsmiths, tapestries, incense and bakers. In the Synagogue, ran by the Hazzan or synagogue official, Jewish merchants come and discuss their grievances in the trade, political sentiments or take collective action, if necessary.(Haas, 1997)

Almost immediately following the founding of Alexandria in the fourth century BCE, a large number of Jews immigrated to the city and made it their home. Originally only settling in the Delta quarter of the city, the Jewish population spread outwards from there to set up smaller neighborhoods in other quarters of the city as evidenced by the synagogues and other cultural artifacts that they left behind. These Jews gradually became Hellenized to the extent that Greek was used more than Hebrew in their community, and necessitated the translation of the Torah into Greek. When the Ptolemaic dynasty that had ruled Alexandria since Alexander the Great's death finally fell to the Romans in the late first century BCE, the Jewish community enjoyed many of the same privileges that it had under the Hellenic kingdom. Interestingly enough, many Romans saw the Jewish community of Alexandria as a good ally against the city's other Greek and Egyptian inhabitants - there were many different influential Romans who could court the Jewish community in Alexandria and its various factions for their support. The same was true of the opposite - many people of the Jewish community and its various factions tried to gain the support of the Roman Emperor or of his close allies or family members. Making up a large proportion of the city's population, Alexandria's Jews were the largest and most influential minority.

The expansion of the Jewish ethnic community was limited in Graeco Roman Alexandria. Although they were able to develop their independent social and political institutions yet, they were not permitted to go further into the social and political life of the natives. There were certain districts outside Alexandria known to be as Jewish districts such as Memphis. The evidence of Jewish communities in Alexandria are scattered. The earliest reference can be attributed to Josephus of the first century AD mentioning that the Jews were settled in Alexandria by Alexander himself. Later on, it was known that they concentrated in the Delta quarter and another one in the five quarters of the city. They were attracted to the Hellenistic culture and civilization of the city. Alexandria was growing as the capital of the civilized world. (Haas, 1997)

\section{Ethnic Minorities and Christianity}

Both the Jewish community and the Negroids were responsible for the appearance of Christianity during the Hellenistic period. This is another reason why they were discriminated against for not participating in the Greco-Roman activities that occurred in Egypt. However, this was mainly due to Negroids not participating in religious activities and promoting Christianity in Alexandria with the help of Saint Frumentius. Saint Frumentius went to Alexandria and said it was wrong for the Christian Greeks in the mid-fourth century to hide their work of God. As a result, Saint Frumentius introduced Christianity to the Negroids that inhabited Alexandria. He said he was given grace because of the countless number of barbarians that were converted to Christianity (Burstein, 1998) The Jewish people who also considered themselves Christians believed that there was a "Messianic occurrence," where a man who possessed leadership characteristics and did a passage out of wilderness was a man that was sent by God to save the Jewish community. One of mistaken messiahs was Simon bar Kokhba, who was the commander and chief during the Bar Kokhba revolt in Israel had established an independent Jewish state before the Romans invaded. However, the Jewish-Christians though the true messiah was Jesus and spread the message of his word with the Negroids in Alexandria. This contributed to not only the culture and religion of Alexandria but also to the culture of the Hellenistic era. (Peasron, 2003)

As the rulers of Alexandria changed, so did the attitudes towards minorities. One of the worst Emperors was Diocletian, who was responsible for the destruction of all Alexandrian churches and killed many Christians in the process. The acceptance of Christianity was not completely accepted until the Emperor Constantine declared it the official language, finally stopping all of the persecution. These Christians in Egypt were eventually given the name Copts and many Coptic Churches began to be constructed (Forster, 1961). In terms of the Jewish population, they received persecution under the ruler Caligula, where many Jews were killed. In 38 B.C., there was a massive riot against the Jews, resulting in many deaths and the destruction of many synagogues. As soon as Caligula was no longer in power, Emperor Claudius did the honor of giving the Jews the right to worship as they please again (Vrettos, 2001). As a group, Claudius did not grant the Jews the right of citizenship though (Casey, 1925). During the $4^{\text {th }}$ century, many Christians grew strongly against the Jews (Rutgers, 1992). 
According to the Egyptian Church, Alexandria was introduced to Christianity in 45 A.D. by St. Mark. But this led to some tension due to the beginning of protests against the Greco-Egyptian beliefs. One of St. Mark's converts, a man named Annianus, began denouncing the worship of Serapis as a god, beginning a feud with Emperor Hadrian. Hadrian began having a very negative opinion of the Christians in which he referred to them as "seditious, vain, spiteful..." Hadrian viewed the Christian god as mediocre, whom was also worshipped by the Jews, and considered them misbehaved. As an entire group, the Christians felt obligated to not worship the Emperor as a godly figure, due to their own views of God. In honor of St. Mark, a gathering place was created, which was later transformed into a large Cathedral dedicated to Virgin Mary (Forster, 1961).

\section{Jewish Minority Influence}

Though, the Jewish community that was involved in economic and political activity of the Greeks and Romans, they were perceived as snobbish because they rarely participated in Graeco-Roman social life. The exclusiveness of the Jewish community made them very strong because they were able to keep their faith and participate with the Greeks and Romans outside of their community. For example, the Jewish people placed images and statues of their admirers in Apion's temple, one of which was an image of Moses seated on a donkey. Apion, a Graeco-Egyptian teacher and grammarian, took pleasure in ridiculing the Jewish community by putting a statue of himself in the Jewish temple (BarKochva, 2010) This resulted in the fear and hatred of the Jewish community because the Jewish community was allowed to reside in the area outside of their district in Alexandria. But none of the Jewish people wanted to stay in their district in Alexandria, Delta. Not only did this was there anti-Semitism in Alexandria, Egypt, but it led to many Jewish revolts against the Greeks and Roman (Daniel, 1979)

There was always hatred and discrimination of the Jewish community. For example, Hadrian blamed the Jewish community for the destruction of the Alexandria in terms of the Synagogues and the roads that connected to the international trade routes. The Jewish revolt began in October 115 A.D. with Emperor Parthian and his reduction of garrison troops. His garrison troops from Nicopolis met Jewish revolts but defeated them in a decisive victory that ended the revolt in Alexandria in 177 A.D. Because most of the Jewish people lost the revolt, most fled to Palestine for safety due to the genocide of the Jewish people in Alexandria. In 132 A.D., the Jewish community established six independent states in Israel but the Roman army crushed them all under Hadrian and barred all Jews from Jerusalem, including Jewish Christian who inhabited Israel (Haas, 1997)

\section{Jewish and other minority relations}

Even though Alexandria was known for its architecture and wealth of goods and services during the Hellenistic period, there was a struggle in the ethno-religious communities for survival in Alexandria. This is because of the Greek and Roman discrimination against the Negroid and the Jewish community. Negroids contributed their resources from the Kush region of current Ethiopia, which contained ivory, ebony, gold and silver. However, because the Greeks and Romans wanted the resources, they fought the Negroids and made them slaves, instead of sharing the resources between each other. The Jewish community contributed their mastery of popular goods such as metal products, bakery goods and incense as well as their ideals of politics (Snowden, 1970) but because of false assumptions about the Jewish community being snobbish, they were discriminated and devalued as a community when the Roman army took their land and committed genocide of the people. Both Negroids and the Jewish people contributed to the rise of Christianity as well in Alexandria but they were still not respected by the Greeks and Romans, thereby caused war and revolts arose late antique Alexandria.

Also problematic for the relationship between Jews and Egyptians, and to a lesser extent the Greek population, was the quintessential monotheism of the Judean people. The "religious peculiarity" of the Jewish community was seen as distrustful by powerful Egyptians, for whom religious and political authority was synonymous. Though the dominant Greek culture during the Ptolemaic period was polytheistic and adopted many ancient Egyptian religious conventions, such as cult to kings, it was generally not expected that all members of society were required to belong to the state religion - a religious tolerance for the most part shared by later Roman rulers. Due to the Graeco-Roman style of rule, the religious differences of the Jews was not a major cause for anti-Semitism by the ruling classes. However, as earlier mentioned, the Egyptians didn't trust the monotheistic Jews and could often tell stories in order to bring disfavor upon the community; Egyptian priests with influence over nonnative rulers were some of the biggest perpetrators of this transgression. For instance, the Egyptian priest Manethoin the court of Ptolemy II Philadelphos was deeply suspicious of the Hyksos regime associated with Judaea, which devastated Egyptian culture. He started and spread popular legends about the segregation of a crowd of lepers by the priest Osarseph (Moses) who refused to worship the Egyptian gods, sacrificed and consumed sacred animals, and advocated social isolation. Most odious to Osareph and the Egyptian religion was the Jews' disdain of animal cults (Barclay, 1999). This aspect of the two religions caused the most contention due to the communities, due to the severely opposing opinions about it. For the Egyptians, it was not only common but expected that gods would be represented as both animal and human deities, and certain animals associated with certain gods were considered extremely holy to them-for instance the bull to Osiris/Serapis, and the ibis and baboon to Thoth. However, this practice of association and equation of animal with god violated the very basic tenets of the monotheism of the Jews, more so even than other cultures' worship of multiple gods. For this reason there was more religious tension between the Jews and Egyptians than between the Jews and Greeks or Romans. Though the 
Greeks would sometimes mention gods appearing as animals as myth-Zeus often appeared as bulls and birds to his human lovers - they never put these animals on the same level as the gods. Just because a Greek god may have been represented as animals, these animals were not the gods, and not every one of those animals was seen as sacred. Certain animals were considered sacred in the Graeco-Roman world (such as the she-wolf to the Romans), but never considered to be equivalent to the gods.

There was, however, quite a bit of anti-Semitism in Roman Alexandria. This prejudice had more to do with the more elevated status of the Jewish community than that of the native Egyptians, and in the very early years of Roman rule, than even the Greeks in terms of privilege. The Jewish community of the city may have, according to the historian Josephus, been granted special privileges (compared to other non-citizens) and a home in the Delta quarter of the city as early as the mid $4^{\text {th }}$ century BCE, maybe even by one of the first Ptolemy's - whether by Soter or Philadelphos is disputed (Watts,2008). Though there were many cases when the Jews became political enemies and vicitms of certain Ptolemy's for various political reasons, the community made peace with Ocatvian at the very start of the Roman period, at which time he confirmed their special privileges among non-Greeks, among these their own council of elders (Bell, 1941).

While these privileges, which gave the Jewish community the ability to live independently of the Greek authority's influence (though they often embraced Greek culture, the Jewish poet Philo's brother was in fact very influential and held public office and was a friend with the Emperor Claudius), existed during the Ptolemaic period, it wasn't until the beginning of Roman rule that their status caused problems with the Greeks. While the privileges of the Jewish community to hold an independent council was upheld by Octavian in thanks for their support of his takeover,

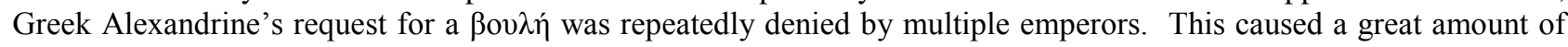
tension between the Jewish and Greek communities, and the citizens continuously pushed for discrimination against the Jews in the hopes to gain them more rights. For Alexandria was "a city that imposes its will upon its governors; the people and the city itself were easily moved to rebellion" (Watts, 2008)—from ExpositioTitius Mundi etGentium). The Greek's disdain for the Jews led to many campaigns into the Delta quarter and destruction of synagogues throughout the city during the Roman period, from the massacre perpetrated by Flaccus and documented by Philo in 38 CE to the civil war of 66 quashed by the governor Tiberius Julius Alexander (in fact a nephew of Philo and himself a Jew) to the revolt from 116 to 117 in Cyrenaica which brought about a massacre in Alexander from which the Jewish community never truly recovered - and in fact kept the Jewish community silent for two centuries (Barclay,1999). Then in the fifth century CE, at the behest of the Christian saint Cyril, a mob was called against the Jews and synagogues turned into churches, and Jews expelled en masse, spelling the end of the Jewish community in Alexandria until the modern age (Bell 1927).

On the other hand, the lives of the native Egyptians - the largest population of which was a small community of weavers in the southwest area of Rhakotis - was relatively stable in its denial of rights. While Egyptian religious officials had generally held important positions in the Ptolemaic court, and were still seen as an important bridge to the rest of Egyptian society, they held no real power within either the Greek kingdom or Roman province. Egyptians were seen as neither citizens nor independent peoples, and were treated as foreigners in their own country. While the Roman government tried to counteract this truth by dedication of temples and building of public buildings and monuments, they at the same time would heavily tax the residents in order to fund military campaigns and building projects, though they denied the Egyptians any form of citizenship, including exclusion from the military. Though this changed slightly with Caracalla's declaration of the Constitutio Antoniniana in $212 \mathrm{CE}$, which granted citizenship to nearly all freed peoples within the empire, the act was merely a money-making measure, and made Egyptians liable to the poll-tax while still ineligible for military service (Jones, 1936).

Altogether the Jewish and native Egyptian communities of Alexandria lived at a certain level of animosity in their relations due to both religious differences and inequalities. Though both were non-citizens under a Greek majority, the two communities were at the same time on very different levels. The Jewish community enjoyed a certain level of autonomy, while the native Egyptians were treated no better than any foreigner - and in many ways worse due to their roots in the countryside. However, it was in many ways their unassuming county nature and willingness to comply with the reality of non-citizenship that allowed the Egyptian community to survive while the Jews of Alexandria were decimated time and time again.

\section{Conclusion}

The Jewish, native Egyptians and other communities of Alexandria lived at a certain level of animosity in their relations due to both religious differences and inequalities. Though they were all non-citizens under a Greek majority, these communities were at the same time at very different levels. The Jewish community enjoyed a certain level of autonomy, while the native Egyptians were treated no better than any foreigner - and in many ways worse due to their roots in the countryside. However, it was in many ways their unassuming county nature and willingness to comply with the reality of non-citizenship that allowed the Egyptian community to survive while the Jews of Alexandria were decimated time and time again. 


\section{Bibliography}

- $\quad$ Alston, R. (1997) "Philo's 'In Flaccum': Ethnicity and Social Space in Roman Alexandria." Greece \& Rome. 44.2, pp.165175. Print. <http://www.jstor.org.ezproxy2.rmc.edu/

- $\quad$ Armstrong, L (1993) A History of God. New York: Alfred A. Knopf, Inc,.

- Bar-Kochva, B (2010) The Image of the Jews in Greek literature: The Hellenistic Period, Los Angeles, California: University of California Press, p.242

- $\quad$ Barclay, J.C. (1999) Jews in the Mediterranean Diaspora: From Alexander to Trajan (323 BCE-117 CE), University of California Press , pp 22-30

- Bell, H.I. (1941) "Anti-Semitism in Alexandria." Journal of Roman Studies. $31 . \quad$ Print. <http://www.jstor.org.ezproxy2.rmc.edu/stable/297098>.pp.1-18

- $\quad$ Bell, H.I (1927) "Alexandria" The Journal of Egyptian Archaeology Vol 13 No3/4 London, pp. 171-184

- $\quad$ Biale, D. (2002) Cultures of the Jews: A New History. Random House, Print.

- $\quad$ Burstein, S. (1998) Ancient African Civilizations: Kush and Axum, Princeton, New Jersey: Markus Wiener Publishers, pp. $8-10$

- $\quad$ Casey, R.P. (1925)"New Papyri concerning Incidents at Alexandria." The Harvard Theological Review 18.3. pp. 285-90.

Web.

- $\quad$ Delia, D.(1998) "The Population of Roman Alexandria" Transaction of American Philological Association, John Hopkins University Press 118, pp 275-292 http://www.jstor.org/stable/284172, accessed April 28 $8^{\text {th }}, 2013$.

- $\quad$ Forster, E. (1961) Alexandria: A History and Guide. Garden City, N. Y.: Doubleday

- $\quad$ Haas, C. (1997) Alexandria in Late Antiquity: Topography and Social conflict, Baltimore, Maryland: The Johns Hopkins University Press, pp.96-97,113-114

- Hadas, M. (1950) “Aspects of Nationalist Survival under Hellenistic and Roman Imperialism,” The Journal of History and Ideas Vol 11, 1950. http://www.jstor.org/stable/2707242, accessed April $28^{\text {th }}, 2013$

- $\quad$ Daniel, J (1979) “Anti-Semitism in the Hellenistic-Roman period", Westfield, New Jersey:Journal of Biblical Literature, pp. 58-59

- Jones, H.(1926) "Claudius and the Jewish Question at Alexandria," in The Journal of Roman Studies Vol 16 http://www.jstor.org/stable/295680, accessed April $28^{\text {th }}, 2013$ p.223

- Jones, A.H.M.(1936) "Another Interpretation of the Constitutio Antoniniana'." Journal

of Roman Studies. 26. Part 2 pp.223-235. Print. <http://www.jstor.org.ezproxy2.rmc.edu/stable/296867>.

- Michele R. (2006) "Biological and Ethnic Identity in New Kingdom Nubia" University of Alberta: The Wenner-Gren Foundation for Anthropological Research, p.683

- Milne, J.G. (1901)"Greek Inscriptions from Egypt." Journal of Hellenic Studies 21.pp 275-292. Print. <http://www.jstor.org.ezproxy2.rmc.edu/stable/623876>.

- Pearson, B. (1986) "Christians and Jews in First-Century Alexandria," The Harvard Theological Review Vol 79, http://www.jstor.org/stable/1509413, accessed April 28 ${ }^{\text {th }}, 2013$.

- $\quad$ Pearson, B. (2003)“Cracking a Conundrum: Christian origins in Egypt,” Taylor \& Francis group: StudiaTheologica 64,pp 208-210

- $\quad$ Riggs, C. (2012) Oxford Handbook of Roman Egypt, United Kingdom: Oxford University Press,p. 103

- $\quad$ Rutgers, . (1992) "Archaeological Evidence for the Interaction of Jews and Non-Jews in Late Antiquity." American Journal of Archaeology 96.1 pp.101-18. Web.

- Snowden, Jr, Frank M. (1970) Blacks in Antiquity: Ethiopians in the Greco-Roman Experience, Cambridge, Massachusetts: Harvard University Press, p.128

- $\quad$ Vrettos, Theodore. (2001) Alexandria: City of the Western Mind. New York: Free, 2001. Print.

- Watts, E. (2008) City and school in late antique Athens and Alexandria. Reprint. Berkeley: University of California Press,pp151-54.eBook.

http://books.google.com/books?id=CGPSnhlQYcAC\&pg=PA151\&dq=nativeEgyptiancommunityromanAlexandria\&hl=en\&sa=X\&e $\mathrm{i}=$ ceZ_Ud2RJ4ia8gTxt4HQBQ\&ved=0CC8Q6AEwAA

- Wolfson, H (1944) "Philo on Jewish Citizenship in Alexandria," in Journal of Biblical Literature Vol 63. http://www.jstor.org/stable/3262653, accessed April $28^{\text {th }}, 2013$.

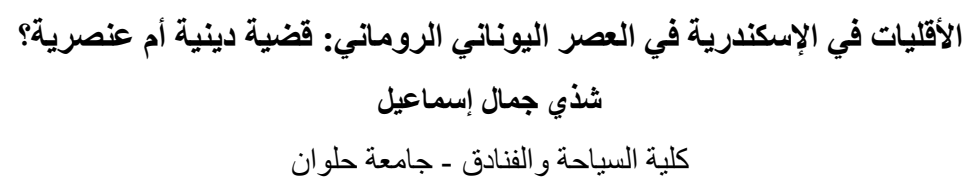

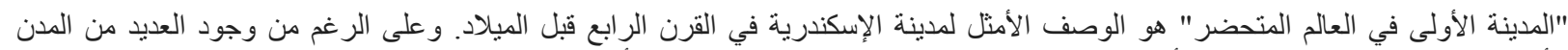

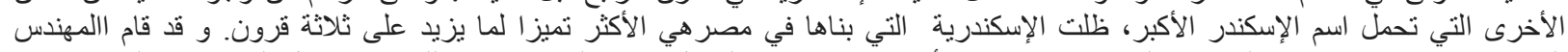

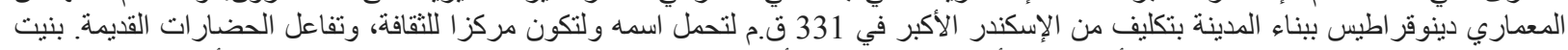

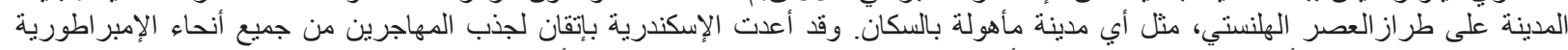

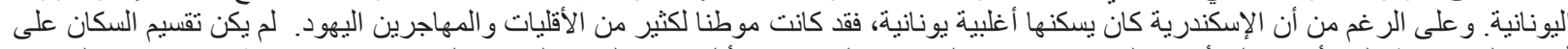

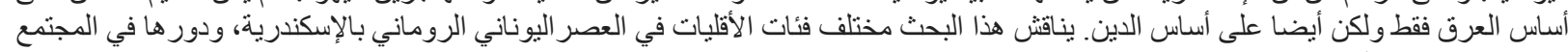
و علاقتهم ببعضهم البعض. 